\title{
Residual effect of pig slurry on common carpet grass pasture
}

\author{
Daiane C. K. Albuquerque ${ }^{1}$, Simone M. Scheffer-Basso ${ }^{2}$, Pedro A. V. Escosteguy ${ }^{2}$, \\ Karen D. Brustolin-Golin ${ }^{3}$, Valdirene Zabot $^{4} \&$ Mario Miranda ${ }^{5}$ \\ ${ }^{1}$ Aurora Alimentos. Chapecó, SC. E-mail: daiane-carla@auroraalimentos.com.br \\ ${ }^{2}$ Universidade de Passo Fundo/Faculdade de Agronomia e Medicina Veterinária/Programa de Pós-Graduação em Agronomia. Passo Fundo, RS. E-mail: \\ sbasso@upf.br; escosteguy@upf.br \\ ${ }^{3}$ Universidade Comunitária Regional de Chapecó/Área de Ciências Exatas e Ambientais. Chapecó, SC. E-mail: karen.db@unochapeco.edu.br (Corresponding \\ author) \\ ${ }^{4}$ Universidade do Oeste de Santa Catarina/Faculdade de Medicina Veterinária. Xanxerê, SC. E-mail: valzabot@hotmail.com \\ ${ }^{5}$ Empresa de Pesquisa Agropecuária e Extensão Rural de Santa Catarina. Chapecó, SC. E-mail: mirandatigre51@gmail.com
}

Key words:

nitrogen uptake

dry matter yield

manure

\begin{abstract}
A B S T R A C T
This study investigated the residual effects of pig slurry (PS) applied to common carpet grass pasture (Axonopus affinis) for two years (September 2008-March 2010) on dry matter yield and forage-nitrogen uptake from October 2010-May 2011. A field experiment was conducted in a randomized complete block design with four replications. The treatments were $102,204,306,408$, and $510 \mathrm{~m}^{3} \mathrm{ha}^{-1}$ pig slurry applied for two years; one mineral nitrogen rate $\left(1,250 \mathrm{~kg} \mathrm{ha}^{-1}\right.$ ammonium nitrate) for two years; and no nitrogen fertilization (control). The pasture was cut at intervals of 48, 34, 43 and 69 days, which corresponded to $266,300,343$, and 412 days after the last fertilizer application, respectively. Dry matter yield increased by $398 \mathrm{~kg} \mathrm{ha}^{-1}$ for each $100 \mathrm{~m}^{3}$ of PS applied, the equivalent of 317 and 564 $\mathrm{kg} \mathrm{ha}^{-1}$ for each $100 \mathrm{~kg} \mathrm{ha}^{-1}$ of inorganic and organic $\mathrm{N}$ applied, respectively. The residual effect of PS on dry matter yield and forage-nitrogen uptake ranged from $11-45 \%$ and $8-40 \%$, respectively, indicating a gradual release and availability of $\mathrm{N}$ in PS, which can help reduce the amounts of nitrogen applied to pasture.
\end{abstract}

\section{Palavras-chave:}

esterco

absorção de nitrogênio produção de forragem

\section{Efeito residual de dejeto líquido de suínos em pastagem de grama-tapete comum}

\section{R E S U M O}

Verificou-se, neste estudo, o efeito residual de dejeto líquido de suíno aplicado em pastagem de grama-tapete comum (Axonopus affinis) durante dois anos (setembro 2008 a março 2010), por meio da avaliação da produção de matéria seca e da absorção do nitrogênio na forragem, no período subsequente (outubro 2010 a maio 2011). Um experimento no campo foi realizado em delineamento de blocos completos casualizados, com quatro repetições. Os tratamentos foram cinco doses de dejeto $\left(102,204,306,408\right.$ e $510 \mathrm{~m}^{3} \mathrm{ha}^{-1}$ por dois anos), ausência de adubação nitrogenada (tratamento-controle) e uma dose de nitrogênio mineral (1.250 kg ha-1 de nitrato de amônio, por dois anos). A pastagem foi cortada em intervalos de 48,34, 43 e 69 dias, que corresponderam a 266, 300, 343 e 412 dias após a última aplicação dos fertilizantes, respectivamente. A taxa de produção de matéria seca aumentou em $398 \mathrm{~kg} \mathrm{ha}^{-1}$ para cada $100 \mathrm{~m}^{3}$ do dejeto de suínos previamente aplicados, equivalente a 317 e $564 \mathrm{~kg} \mathrm{ha}^{-1}$ para cada $100 \mathrm{~kg} \mathrm{ha}^{-1}$ da forma inorgânica ou orgânica de nitrogênio, respectivamente. $\mathrm{O}$ efeito residual do dejeto líquido de suínos na produção de matéria seca variou de 11 a 45\% e na absorção do nitrogênio da forragem variou de 8 a $40 \%$, indicando liberação gradual ou disponibilidade do $\mathrm{N}$ no dejeto, o que contribuiria para a redução das quantidades de nitrogênio a serem aplicadas na pastagem. 


\section{INTRODUCTION}

Pig slurry (PS) is an organic alternative to chemical nitrogen $(\mathrm{N})$ fertilizers that can increase production of winter and summer crops (Seidel et al., 2010; Moraes et al., 2014; Basso et al., 2016) and of cover crops (Aita et al., 2006). Many studies have found an increase in dry matter yield (DMY) of pastures in response to PS fertilization (Vielmo et al., 2011; Miranda et al., 2012; Zanine \& Ferreira, 2015). A significant part of the organic $\mathrm{N}$ retained in the soil after PS application is derived from immobilized ammonium- $\mathrm{N}$, which is slowly released over many years (Sorensen \& Amato, 2002). These N forms may remain in the soil at the end of the growing season, benefitting subsequent crops, which is known as the residual effect. Thus, the amount of $\mathrm{N}$ available in the years following PS application should be determined and considered during fertilization planning (Yagüe \& Quílez, 2013).

It has been suggested that manures may only have a benefit on soil productivity, over and above their nutrient content, when large inputs are applied over many years (Edmeades, 2003). In fact, residual PS fertilizer applied to Brachiaria brizantha (Hochst ex A. Rich) Stapf. pastures only increased nutrient levels in the leaves and soil starting a year after application (Teixeira et al., 2012).

This study investigated the residual effects, on common carpet grass (Axonopus affinis Chase) pastures' dry matter yield and $\mathrm{N}$ uptake, of PS application in the year subsequent to two years of slurry applications. Carpet grass is a grazingand cold-resistant, warm-season grass that is among the most important grasses of natural grasslands in southern Brazil.

\section{Material ANd Methods}

The experiment was conducted at Epagri Station, Chapecó in the state of Santa Catarina, Brazil ( $27^{\circ} 7^{\prime} \mathrm{S}, 52^{\circ} 37^{\prime} \mathrm{W}, 679$ $\mathrm{m}$ elevation). The climate in the region is humid subtropical (Cfa). The study was performed between December 2010 and May 2011 following two years (2008-2010) of PS fertilization on a common carpet grass pasture.
The treatments consisted of five PS application rates, calculated to provide 100, 200, 300, 400, and $500 \mathrm{~kg} \mathrm{ha}^{-1}$ year $^{-1}$ $\mathrm{N}$, one ammonium nitrate (AN) application rate equivalent to $200 \mathrm{~kg} \mathrm{ha}^{-1} \mathrm{~N}$, or no nitrogen fertilization (PSO + ANO) (Brustolin et al., 2016). The soil in the experimental area is an Oxisol, with clay testure in the 0-0.05 m layer. Before each application, PS was analyzed for concentrations $\mathrm{N}$ in the inorganic, organic and total fractions, according to Tedesco et al. (1995), in order to calculate the appropriate amount of PS to be applied in each treatment (Table 1).

After two years of PS or AN applications, the soil chemical attributes were analysed (Table 2) according to Tedesco et al. (1995), after which this study started, in October 2010. The experiment was conducted in a randomized complete block design with four replications. The residual PS effect was estimated by quantifying dry matter yield (DMY) and foragenitrogen uptake (FNU).

The pasture was cut when plants in the plots that received ammonium nitrate reached an average height of $\sim 18 \mathrm{~cm}$, and then at intervals of 48 (December 2010), 34 (January 2011), 43 (February 2011), and 69 (May 2011) days, corresponding to $266,300,343$, and 412 days after the last application of $\mathrm{N}$ fertilizers. The plants were cut from the inner $1 \times 5 \mathrm{~m}\left(5 \mathrm{~m}^{2}\right)$ area of each $30 \mathrm{~m}^{2}$ plot, to an $8-\mathrm{cm}$ stubble height, with a power mower. Samples were taken for dry matter (DM) content

Table 1. Pig slurry (PS) and ammonium nitrate (AN) rates and the equivalent amounts of inorganic, organic, and total nitrogen $(\mathrm{N})$ applied for two years (2008-2010) on common carpet grass pastures

\begin{tabular}{|c|c|c|c|}
\hline \multirow{2}{*}{$\begin{array}{l}\text { Previous fertilization } \\
\text { (qty ha }^{-1} 2 \text { years }^{-1} \text { ) }\end{array}$} & Inorganic N & Organic N & Total N \\
\hline & \multicolumn{3}{|c|}{$\mathrm{kg} \mathrm{ha}^{-1} 2$ years $^{-1}$} \\
\hline $1,250 \mathrm{~kg}$ AN & 400 & 0 & 400 \\
\hline $102 \mathrm{~m}^{3} \mathrm{PS}^{*}$ & 128 & 72 & 200 \\
\hline $204 \mathrm{~m}^{3} \mathrm{PS}$ & 256 & 144 & 400 \\
\hline $306 \mathrm{~m}^{3} \mathrm{PS}$ & 384 & 216 & 600 \\
\hline $408 \mathrm{~m}^{3} \mathrm{PS}$ & 512 & 288 & 800 \\
\hline $510 \mathrm{~m}^{3} \mathrm{PS}$ & 640 & 360 & 1000 \\
\hline
\end{tabular}

*Rates based on the nitrogen content of pig slurry (Brustolin et al., 2016) calculated according to methods described by Tedesco et al. (1995)

Table 2. Soil chemical attributes and critical levels (CL) at the beginning of the experiment (October 2010) in plots without nitrogen fertilization (N0) and after two years of pig slurry (PS) and ammonium nitrate (AN) applications on common carpet grass pasture

\begin{tabular}{|c|c|c|c|c|c|c|c|c|}
\hline \multirow{3}{*}{ Soil attribute } & \multicolumn{7}{|c|}{ Previous fertilization (qty ha ${ }^{-1} 2$ years ${ }^{-1}$ ) } & \multirow{3}{*}{ CL } \\
\hline & \multirow[t]{2}{*}{ NO } & \multirow{2}{*}{$\begin{array}{c}\text { AN } \\
\left(\mathrm{kg} \mathrm{ha}^{-1}\right) \\
1,250\end{array}$} & \multicolumn{5}{|c|}{$\begin{array}{c}\text { PS } \\
\left(m^{3} \mathrm{ha}^{-1}\right)\end{array}$} & \\
\hline & & & 102 & 204 & 306 & 408 & 510 & \\
\hline $\mathrm{pH} \mathrm{H} \mathrm{H}_{2} \mathrm{O}$ & 5.8 & 5.4 & 5.6 & 5.7 & 5.5 & 5.5 & 5.4 & 5.5 \\
\hline$P\left(\mathrm{mg} \mathrm{L}^{-1}\right)$ & 21.3 & 14.9 & 25.8 & 15.4 & 17.2 & 20.0 & 21.7 & $>9.0$ \\
\hline $\mathrm{K}\left(\mathrm{mg} \mathrm{L}^{-1}\right)$ & 240.3 & 170.3 & 200.0 & 186.3 & 197.0 & 181.0 & 153.0 & $>90.0$ \\
\hline Organic matter $\left(\mathrm{g} \mathrm{dm}^{-3}\right)$ & 52.0 & 51.0 & 56.0 & 55.0 & 57.0 & 52.0 & 53.0 & $>50.0$ \\
\hline $\mathrm{Al}\left(\mathrm{cmol}_{\mathrm{c}} \mathrm{dm}^{-3}\right)$ & 0.0 & 0.0 & 0.0 & 0.0 & 0.0 & 0.0 & 0.0 & - \\
\hline $\mathrm{Ca}\left(\mathrm{cmol}_{\mathrm{c}} \mathrm{dm}^{-3}\right)$ & 7.0 & 6.0 & 6.1 & 6.3 & 6.5 & 6.8 & 5.8 & $>4.0$ \\
\hline $\mathrm{Mg}\left(\mathrm{cmol}_{\mathrm{c}} \mathrm{dm}^{-3}\right)$ & 4.5 & 3.2 & 3.8 & 4.0 & 4.0 & 4.3 & 3.6 & $>2.0$ \\
\hline $\mathrm{H}+\mathrm{Al}\left(\mathrm{cmol}_{\mathrm{c}} \mathrm{dm}^{-3}\right)$ & 5.6 & 4.6 & 6.6 & 6.4 & 6.9 & 6.7 & 7.1 & - \\
\hline $\mathrm{CEC}\left(\mathrm{cmol}_{\mathrm{c}} \mathrm{dm}^{-3}\right)$ & 17.8 & 14.3 & 17.2 & 17.2 & 18.0 & 18.3 & 17.0 & - \\
\hline$S\left(\mathrm{mg} \mathrm{L}^{-1}\right)$ & 11.0 & 11.0 & 11.3 & 12.6 & 18.0 & 17.0 & 19.3 & $>10.0$ \\
\hline $\mathrm{B}\left(\mathrm{mg} \mathrm{L}^{-1}\right)$ & 0.3 & 0.3 & 0.3 & 0.3 & 0.3 & 0.3 & 0.3 & $\geq 0.3$ \\
\hline $\operatorname{Mn}\left(\mathrm{mg} \mathrm{L}^{-1}\right)$ & 8.5 & 11.3 & 10.2 & 9.5 & 12.1 & 10.8 & 10.2 & $>5.0$ \\
\hline $\mathrm{Zn}\left(\mathrm{mg} \mathrm{L}^{-1}\right)$ & 3.4 & 3.0 & 4.1 & 5.2 & 6.4 & 7.5 & 8.2 & $>0.5$ \\
\hline $\mathrm{Cu}\left(\mathrm{mg} \mathrm{L}^{-1}\right)$ & 2.8 & 2.0 & 2.4 & 2.7 & 2.9 & 3.3 & 3.8 & $>0.4$ \\
\hline
\end{tabular}


determination, dried at $60^{\circ} \mathrm{C}$ for $72 \mathrm{~h}$, then ground. Forage- $\mathrm{N}$ content was determined by near-infrared spectroscopy (NIRS), and FNU was calculated by multiplying DMY by forage-N content. After sampling, the entire plots were mowed to the same stubble height, and the plant material was removed from the plot.

The average pasture response in control plots ( $\mathrm{PS} 0+\mathrm{AN} 0$ ) was estimated from the apparent soil effect (ASE), which was calculated according to methods described by Daudén et al. (2004). The PS apparent residual effect (PSRE) and AN apparent residual effect (ANRE) were calculated for DMY and FNU using Eqs. 1 and 2 (Cela et al., 2011) as follows:

$$
\begin{aligned}
\text { PSRE } & =\text { DMY or FNU in PSi }+\mathrm{N} 0- \\
& - \text { pasture response in PS0 + AN0 } \\
\text { ANRE } & =\text { DMY or FNU in } \mathrm{ANj}+\mathrm{PS} 0- \\
& - \text { pasture response in PSO + AN0 }
\end{aligned}
$$

where:

$$
\begin{aligned}
& \mathrm{i} \quad \text { - PS rate; } \\
& \text { j } \quad \text { - AN rate; } \\
& \text { PSO - no PS application; and, } \\
& \text { AN0 - no AN application. }
\end{aligned}
$$

Differences in DMY and in FNU among PS, AN, and control treatments were determined by analysis of variance (ANOVA) followed by the Dunnett's test $(\mathrm{p}<0.05)$. Linear regression analysis described the relationship between DMY or FNU and PS rates, computing the F-value to determine the significance of the fitted linear regressions $(\mathrm{p}<0.05)$.

\section{Results AND Discussion}

Dry matter yield increased linearly with the rate of PS application (in 2008-2010, Figure 1). This can be attributed to an increasing $\mathrm{N}$ supply, as the levels of other nutrients in the soil were already higher than the critical levels indicated by guidelines for southern Brazil (CQFS-RS/SC, 2004) (Table 2). Furthermore, PS application did not affect soil physical attributes, according to a study performed in a contiguous

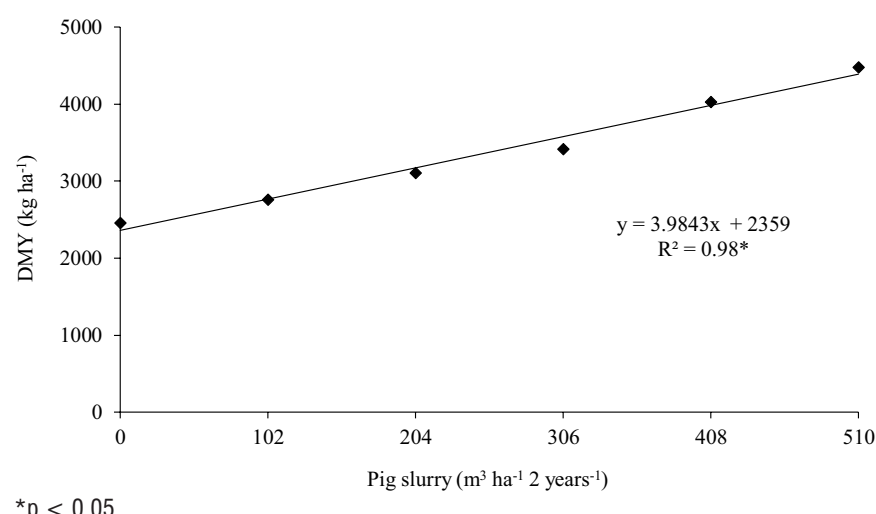

Figure 1. Annual dry matter yield - DMY (2010-2011) of common carpet grass pasture as a function of previous pig slurry rates (2008-2010) area treated with the same PS application rates used in this study (Agne \& Klein, 2014).

Whereas in this study (2010-2011), DMY increased by 3.98 $\mathrm{kg} \mathrm{DM} \mathrm{ha}^{-1}$ year-1 $^{-1}$ for each $\mathrm{m}^{-3}$ PS applied (Figure 1), during the period of application (2008-2010) each $\mathrm{m}^{3}$ PS contributed an average 25,57 $\mathrm{kg} \mathrm{DM} \mathrm{ha}^{1}$ year $^{-1}$ (Brustolin et al., 2016). Thus, the residual nitrogen fertilizer did not provide enough $\mathrm{N}$ to maximize DMY, which reached a maximum value of approximately $4,500 \mathrm{~kg} \mathrm{DM} \mathrm{ha}{ }^{-1}$ year $^{-1}$ one year after the application of PS, compared to an average DMY of 10,019 $\mathrm{kg} \mathrm{DM} \mathrm{ha}^{-1}$ year $^{-1}$ during 2008-2010 (Brustolin et al., 2016).

Because roughly $60 \%$ of the $\mathrm{N}$ applied as PS was available to this pasture in 2008-2010 (Brustolin et al., 2016), it may have accumulated as microbial biomass or other relatively less recalcitrant soil organic compounds. Moreover, some of the PS ammonium-N may have been lost or fixed on clays shortly after its application and some of the organic- $\mathrm{N}$ may have been allocated in stems, leaves, and roots, which is made available over time through senescence. Slurry also stimulates microbial activity leading to increased mineralization of organic matter (Zanine \& Ferreira, 2015).

Forage-N uptake (FNU) also increased linearly with PS application rates (Figure 2). Fine-textured soils (high clay) with high organic matter (OM) content, such as the soils in the experimental area (Table 2), are generally less susceptible to nitrate leaching than sandy-textured soils, as they have high water-holding capacity and low water permeability. Thus, FNU results and soil properties in the area suggest that most of the $\mathrm{N}$ fertilizer applied was retained in the soil without significant leaching.

The apparent soil effect (ASE) was $2,459 \mathrm{~kg} \mathrm{ha}^{-1}$ for annual DMY and $48 \mathrm{~kg} \mathrm{ha}^{-1} \mathrm{~N}$ for FNU, contributing more than 55\% of DMY and $60 \%$ of FNU in unfertilized plots (Table 3). The residual PS effect (PSRE) was smaller and increased with previous fertilizer rates. PSRE ranged from $11\left(102 \mathrm{~m}^{3}\right)$ to $45 \%$ $\left(510 \mathrm{~m}^{3}\right)$ for DMY and $8\left(204 \mathrm{~m}^{3}\right)$ to $40 \%\left(510 \mathrm{~m}^{3}\right)$ for FNU. The residual ammonium nitrate effect (ANRE) of $29 \%$ for DMY and $8 \%$ for FNU was equivalent to $306 \mathrm{~m}^{3}$ of PS (Table 3). Similar results were reported in studies with Axonopus spp. (Miranda et al., 2012; Brustolin et al., 2016) following PS and $\mathrm{AN}$ applications. In these studies, the DMY, at an ammonium nitrate application rate of $200 \mathrm{~kg} \mathrm{ha}^{-1} \mathrm{~N}$, was equivalent to a PS rate calculated to provide $300 \mathrm{~kg} \mathrm{ha}^{-1} \mathrm{~N}$. These results indicate that release of $\mathrm{N}$ from manure was $50 \%$ smaller than from ammonium nitrate.

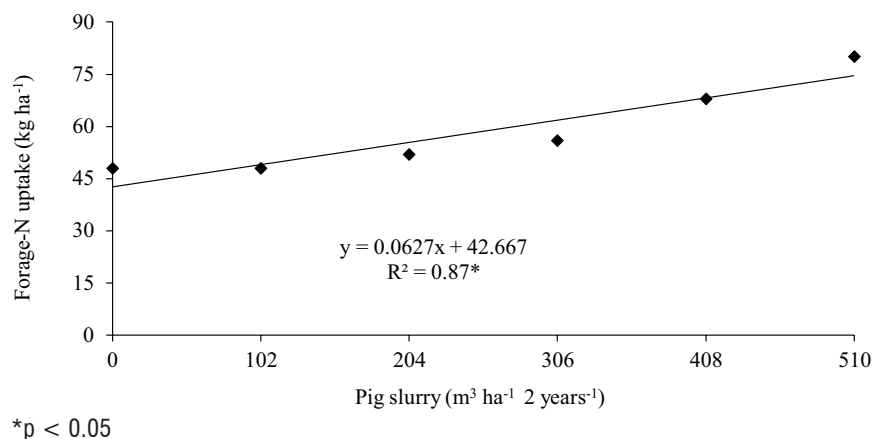

Figure 2. Annual (2010-2011) forage-N uptake of common carpet grass pasture as a function of previous pig slurry rates (2008-2010) 
Table 3. Dry matter yield (DMY) and forage-N uptake (FNU) of common carpet grass pasture (2010-2011) in response to residual effect of pig slurry (PSRE) and ammonium nitrate (ANRE) previously applied (2008-2010), and apparent soil effect (ASE)

\begin{tabular}{|c|c|c|c|c|c|c|c|c|}
\hline \multirow{2}{*}{$\begin{array}{l}\text { Previous fertilization } \\
\text { (qty ha }^{-1} 2 \text { years }\end{array}$} & \multirow{2}{*}{$\begin{array}{c}\text { DMY } \\
\left(\mathrm{kg} \mathrm{DM} \mathrm{ha}^{-1}\right)\end{array}$} & \multirow{2}{*}{$\begin{array}{l}\text { ASE }^{1} \\
(\%)\end{array}$} & PSRE $^{2}$ & ANRE $^{3}$ & \multirow{2}{*}{$\begin{array}{c}\text { FNU } \\
\left(\mathrm{kg} \mathrm{N} \mathrm{ha}^{-1}\right)\end{array}$} & \multirow{2}{*}{$\begin{array}{l}\text { ASE } \\
(\%)\end{array}$} & PSRE & ANRE \\
\hline & & & $(\mathrm{kg}$ & $\left(a^{-1}\right)$ & & & \multicolumn{2}{|c|}{$\left(\mathrm{kg} \mathrm{N} \mathrm{ha}^{-1}\right)$} \\
\hline Control (no N application) & 2,456 ns & - & - & - & $48 \mathrm{~ns}$ & - & - & - \\
\hline $1,250 \mathrm{~kg} \mathrm{AN} \mathrm{ha}^{-1}$ & 3,400 & 72 & - & 941 & 56 & 86 & - & 8 \\
\hline 102 m³ PS ha-1 $^{-1}$ & $2,760 \mathrm{~ns}$ & 89 & 304 & - & $48 \mathrm{~ns}$ & 0 & 0 & - \\
\hline $204 \mathrm{~m}^{3}$ PS ha-1 & $3,108 \mathrm{~ns}$ & 79 & 652 & - & $52 \mathrm{~ns}$ & 92 & 4 & - \\
\hline $306 \mathrm{~m}^{3}$ PS ha-1 & $3,420 \mathrm{~ns}$ & 71 & 964 & - & $56 \mathrm{~ns}$ & 86 & 8 & - \\
\hline $408 \mathrm{~m}^{3}$ PS ha-1 & $4,032 \mathrm{~ns}$ & 61 & 1,576 & - & $68 \mathrm{~ns}$ & 70 & 20 & - \\
\hline $510 \mathrm{~m}^{3}$ PS ha-1 & 4,480 * & 55 & 2,024 & - & $80 \mathrm{~ns}$ & 60 & 32 & - \\
\hline
\end{tabular}

${ }^{*}$ Significant by the Dunnett's test $(p<0.05)$ in relation to AN; ns: Non-significant; ${ }^{1} \mathrm{ASE}$ : PSO or ANO *100)/PS or AN treatment; ${ }^{2} \mathrm{PSRE}$ : Pasture response in PSi + N0 - Pasture response in PSO + ANO; ${ }^{3}$ ANRE: Pasture response in ANj + PSO - Pasture response in PSO + ANO

In annual wheat, the ASE contributed more than $64 \%$ of the grain yield and PSRE was smaller and increased with increasing PS rate, amounting to $36 \%$ of the grain yield (Daudén et al., 2004). In barley (Hordeum vulgare L.), cultivated after four consecutive maize (Zea mays L.) crops fertilized with PS, the PSRE was equivalent to $77 \mathrm{~kg} \mathrm{ha}^{-1} \mathrm{~N}$ of mineral fertilizer, indicating that $\mathrm{N}$ fertilization could be reduced by nearly this amount (Yagüe \& Quílez, 2013). Thus, our findings indicate that previous PS applications can provide $\mathrm{N}$ to subsequent crops and reduce chemical fertilizer inputs in amounts similar to those reported in other studies.

The average PSRE on FNU ranged from $0-5 \%$ of the total inorganic $\mathrm{N}$ input in 2008-2010 (Figure 3), whereas the residual AN effect on FNU was 2\% (data not shown), smaller than the residual effect observed for a similar PS application rate $\left(306 \mathrm{~m}^{3} \mathrm{ha}^{-1}=3.1 \%\right)$. This suggests that PS can provide more residual $\mathrm{N}$ than mineral fertilizer, consistent with the organic fraction of $\mathrm{N}$ of this manure. A significant part of the organic $\mathrm{N}$ retained in the soil after PS application is derived from immobilized ammonium-N, which is slowly released over many years (Sorensen \& Amato, 2002). In addition, the PSRE on FNU ranged from $0-8.8 \%\left(102-510 \mathrm{~m}^{3} \mathrm{ha}^{-1}\right)$ for total organic $\mathrm{N}$ and $0-3.2 \%\left(510 \mathrm{~m}^{3} \mathrm{ha}^{-1}\right)$ for total $\mathrm{N}$.

In the current study, the residual effects of pig slurry applied for two years were evaluated on a permanent grass pasture grown in subtropical conditions. A linear relationship between PS rates and DMY was found, which increased by roughly $4 \mathrm{~kg} \mathrm{ha}^{-1}$ for each $1 \mathrm{~m}^{3}$ PS applied (Figure 1) or the equivalent to $\sim 3 \mathrm{~kg}$ for each $\mathrm{kg}$ of mineral $\mathrm{N}$. In addition to the

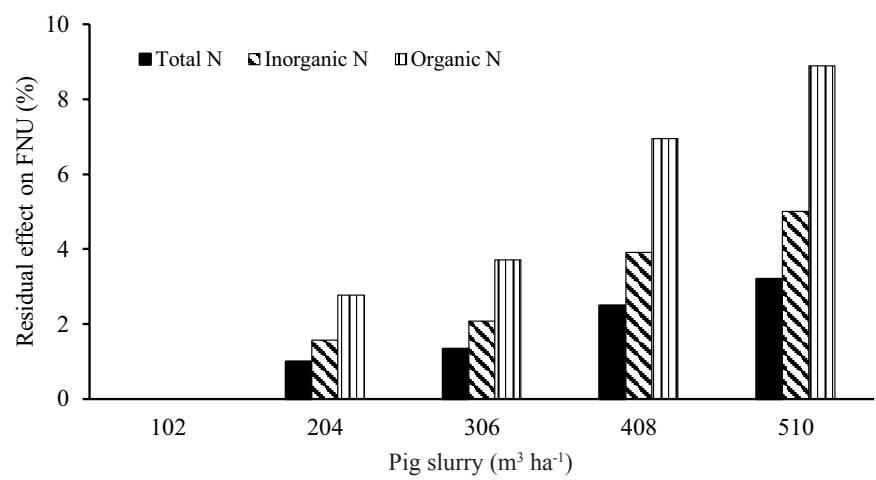

Figure 3. Average residual effect of pig slurry rates on forage-N uptake (FNU) in common carpet grass pastures, considering the previous inputs of total, inorganic, and organic N applied in 2008-2010 well-known advantages of PS fertilization, our findings indicate that this practice can increase the growth of subsequent crops and reduce the cost of nitrogen fertilization.

The results also indicate that manures should preferentially be applied to crops with long growing seasons (e.g., maize, pasture grass, and winter cereals), which can utilize the $\mathrm{N}$ mineralized from the organic $\mathrm{N}$ in the manure. On sandy soils or crops with special quality requirements (e.g., low protein in malting barley), high rates of PS application should be used, with caution to prevent $\mathrm{N}$ build-up, which may pose an environmental risk. Further studies that determine the optimal application rates based on the mineral $\mathrm{N}$ content in the root zone immediately prior to manure application are needed to prevent excess $\mathrm{N}$ accumulation in soils with continuous PS application.

\section{Conclusions}

1. Dry matter yield and forage- $\mathrm{N}$ uptake increased with increasing levels of pig slurry applied to common carpet grass pasture for two years, indicating a gradual release and availability of $\mathrm{N}$ in pig slurry, which can help reduce the amounts of $\mathrm{N}$ applied to pastures.

2. The residual effect of pig slurry varied with application rate, and compared to unfertilized plots, dry matter yield increased from 11 to $45 \%$ (304-2,024 $\left.\mathrm{kg} \mathrm{ha}^{-1}\right)$ and foragenitrogen uptake from 8 to $40 \%\left(4-32 \mathrm{~kg} \mathrm{ha}^{-1}\right)$.

3. The linear response $\left(b=3.98 \mathrm{~kg} \mathrm{~m}^{-3} \mathrm{ha}^{-1}\right)$ of carpet grass to previous pig slurry application resulted in a maximum dry matter yield of roughly $4,500 \mathrm{~kg} \mathrm{ha}^{-1}$.

\section{ACKnOWLedgements}

We thank CNPq for financial support (Project 573577/20080 ), Capes for scholarships to Karen D. Brustolin and Valdirene Zabott, and to Fundação Universidade de Passo Fundo for a scholarship to Daiane Carla Kottwitz.

\section{Literature Cited}

Agne, S.; Klein, V. A. Matéria orgânica e atributos físicos de um Latossolo Vermelho após aplicações de dejeto de suínos. Revista Brasileira de Engenharia Agrícola e Ambiental, v.18, p.720-726, 2014. https://doi.org/10.1590/S1415-43662014000700008 
Aita, C.; Port, O.; Giacomini, S. J. Dinâmica do nitrogênio no solo e produção de fitomassa por plantas de cobertura no outono/ inverno com o uso de dejetos de suínos. Revista Brasileira de Ciência do Solo, v.30, p.901-910, 2006. https://doi.org/10.1590/ S0100-06832006000500016

Basso, C. K.; Pinto, M. A. B.; Santi, A. L.; Silva, R. F. da; Silva, D. R. O. da. Pig slurry as a nutrient source in wheat/corn succession. Revista Ceres, v.63, p.412-418, 2016. https://doi.org/10.1590/0034737X201663030019

Brustolin, K. D.; Scheffer-Basso, S. M.; Escosteguy, P. A. V.; Miranda, M.; Travi, M. R. L.; Zabot, V. Pig slurry in carpet grass pasture: Yield and plant-available nitrogen. Revista Brasileira de Engenharia Agrícola e Ambiental, v.20, p.795-799, 2016. https:// doi.org/10.1590/1807-1929/agriambi.v20n9p795-799

Cela, S.; Santiveri, F.; Lloveras, J. Residual effects of pig slurry and mineral nitrogen fertilizer on irrigated wheat. European Journal of Agronomy, v.34, p.257-262, 2011. https://doi.org/10.1016/j.eja.2011.02.003

CQFS-RS/SC - Comissão de Química e Fertilidade do Solo. Manual de adubação e calagem para os Estados do Rio Grande do Sul e de Santa Catarina. Porto Alegre: SBCS, 2004. 400p.

Daudén, A.; Quílez, D.; Martínez, C. Residual effects of pig slurry applied to a Mediterranean soil on yield and $\mathrm{N}$ uptake of a subsequent wheat crop. Soil Use and Management, v.20, p.156172, 2004. https://doi.org/10.1079/SUM2003230

Edmeades, D. C. The long-term effects of manures and fertilizers on soil productivity and quality: A review. Nutrient Cycling in Agroecosystems, v.66, p.165-180, 2003. https://doi.org/10.1023/A:1023999816690

Miranda, M.; Scheffer-Basso, S. M.; Escosteguy, P. A. V.; Lajús, C.; Scherer, E. E.; Denardin, R. B. N. Dry matter production and nitrogen use efficiency of giant missionary grass in response to pig slurry application. Revista Brasileira de Zootecnia, v.41, p.537543, 2012. https://doi.org/10.1590/S1516-35982012000300009
Moraes, M. T. de; Arnuti, F.; Silva, V. R. da; Silva, R. F. da; Basso, C. J.; Da Ros, C. O. Dejetos líquidos de suínos como alternativa a adubação mineral na cultura do milho. Semina: Ciências Agrárias, v.35, p.2945-2954, 2014. https://doi.org/10.5433/1679$0359.2014 v 35 \mathrm{n} 6 \mathrm{p} 2945$

Seidel, E. P.; Gonçalves Júnior, A. C.; Vanin, J. P.; Strey, L.; Schwantes, D.; Nacke, H. Aplicação de dejetos de suínos na cultura do milho cultivado em sistema de plantio direto. Acta Scientiarum Technology, v.32, p.113-117, 2010.

Sorensen, P.; Amato, M. Remineralisation and residual effects of $\mathrm{N}$ after application of pig slurry to soil. European Journal of Agronomy, v.16, p.81-95, 2002. https://doi.org/10.1016/S11610301(01)00119-8

Teixeira, G. C. da S.; Beltrão, D. S.; Simões, M. L. M.; Leandro, W. M.; Rosa, B. Nutrição e produção de Brachiaria brizantha em função do residual de dejetos de suínos. Revista Agrotecnologia, v.3, p.36-48, 2012. https://doi.org/10.12971/2179-5959.v03n02a04

Tedesco, M. J.; Gianello, C.; Bissani, C. A.; Bohnen, H.; Volkweiss, S. J. Análise de solo, plantas e outros materiais. Porto Alegre: UFRGS, 1995. 175p.

Vielmo, H.; Bona Filho, B.; Soares, A. S.; Assmann, T. S.; Adami, P. F. Effect of fertilization with fluid swine slurry on production and nutritive value of Tifton 85. Revista Brasileira de Zootecnia, v.40, p.60-68, 2011. https://doi.org/10.1590/S1516-35982011000100009 Yagüe, M. R.; Quílez, D. Residual effects of fertilization with pig slurry: Double cropping and soil. Agronomy Journal, v.105, p.70-78, 2013. https://doi.org/10.2134/agronj2012.0191

Zanine, A. de. M.; Ferreira, D. de J. Animal manure as a nitrogen source to grass. American Journal of Plant Sciences, v.6, p.899910, 2015. https://doi.org/10.4236/ajps.2015.67098 